\title{
SULFUR GASES PRODUCED BY THE DECOMPOSITION OF SULFIDE MINERALS: APPLICATION TO GEOCHEMICAL EXPLORATION
}

\author{
CARL H. TAYLOR*, STEPHEN E. KESLER and PAUL L. CLOKE \\ Department of Geological Sciences, University of Michigan, Ann Arbor, MI 48109 \\ (U.S.A.)
}

(Received November 25, 1981; revised and accepted April 7, 1982)

\section{ABSTRACT}

Taylor, C.H., Kesler, S.E. and Cloke, P.L., 1982. Sulfur gases produced by the decomposition of sulfide minerals: application to geochemical exploration. J. Geochem. Explor., $17: 165-185$

We have evaluated the potential application of sulfur gas analysis to exploration for buried sulfide mineral deposits by: (1) calculating by use of equilibrium thermodynamics, the relative abundances of gases that should be given off by decomposing sulfide minerals; and (2) determining experimentally the abundances of gases that are actually given off. The calculations indicate that the gases that should be given off by decomposing sulfide minerals are (in order of decreasing abundance) $\mathrm{H}_{2} \mathrm{~S}, \mathrm{COS}, \mathrm{CS}_{2}, \mathrm{CH}_{3} \mathrm{SH},\left(\mathrm{CH}_{3}\right)_{2} \mathrm{~S}_{2}$ or $\mathrm{SO}_{2}$ or $\mathrm{S}_{2}$ (depending on $\mathrm{Eh}$ and $\mathrm{pH}$ ). In contrast, our experiments show that decomposing sulfide minerals evolve only $\mathrm{CS}_{2}$ and $\mathrm{COS}$, in order of decreasing abundance. Pyrite produces the largest amounts of sulfur gas. Moist (rather than saturated) and non-sterile (rather than sterile) conditions enhance gas generation from pyrite, although no large difference appeared between sterile and non-sterile experiments for other sulfide minerals. These experiments indicate that the sulfur gases $\mathrm{CS}_{2}$ and $\mathrm{COS}$ could be useful indicators of buried metal sulfide deposits.

\section{INTRODUCTION}

The analysis of sulfur gases produced by the decomposition of metallic sulfide minerals could be used in geochemical exploration for concealed mineral deposits (Rose et al., 1979; Lovell et al., 1980). Several investigators have reported field measurements of $\mathrm{H}_{2} \mathrm{~S}$ and $\mathrm{SO}_{2}$ over areas of sulfide mineralization (Elinson et al., 1970; Rouse and Stevens, 1971; Shipulin et al., 1973), but omitted full details of analytical procedures, making critical appraisal difficult. Carbonyl sulfide (COS) and carbon disulfide $\left(\mathrm{CS}_{2}\right)$ as well as $\mathrm{H}_{2} \mathrm{~S}$ have been reported over sulfide mineralization and geothermal areas

\footnotetext{
*Present address: Amoco Production Co., 500 Jefferson Bldg., PO Box 3092, Houston,
} TX 77001 

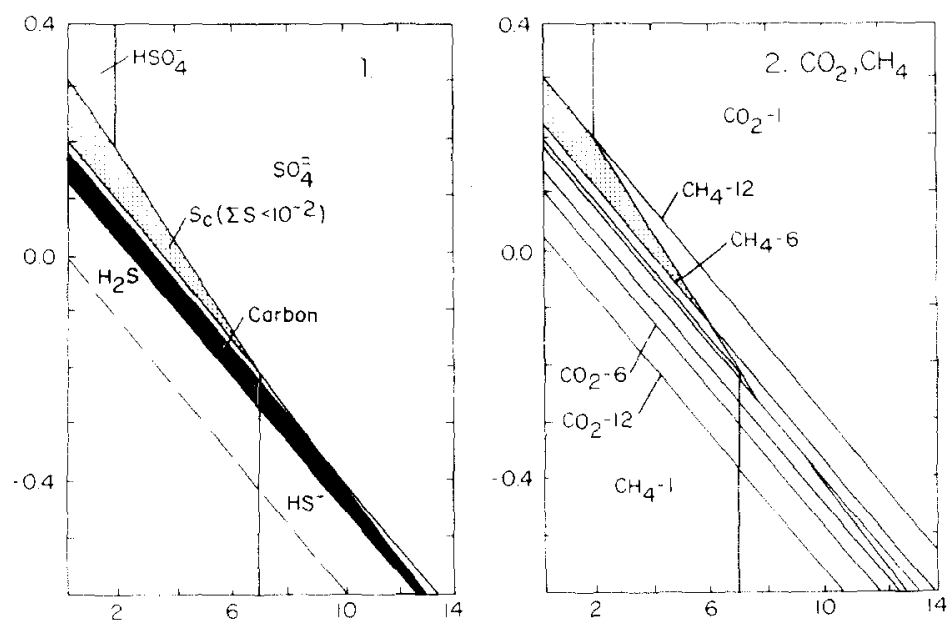

E
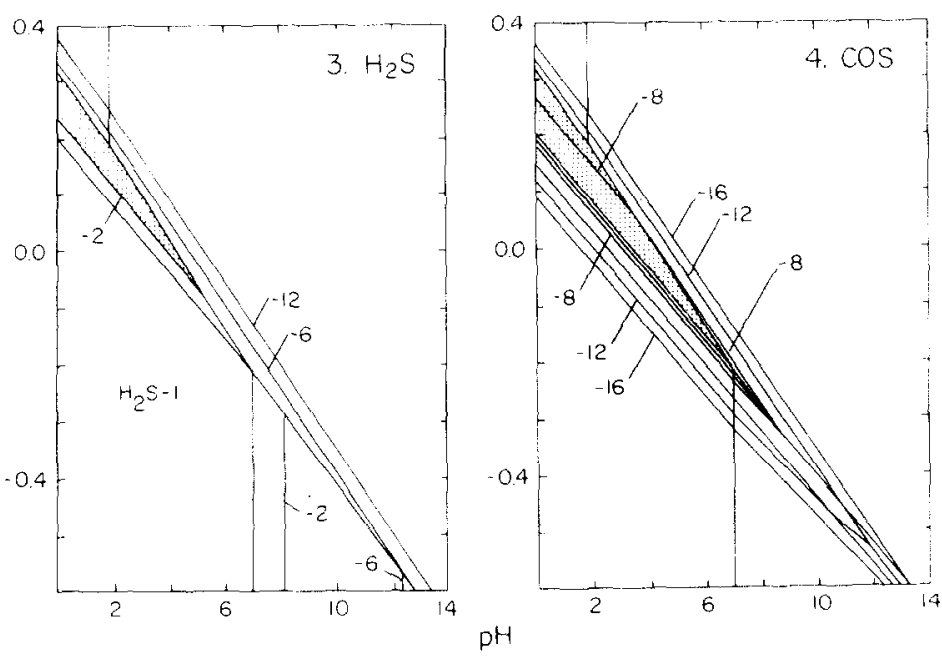

Fig. 1. Dominance fields for aqueous sulfur species. $\mathrm{CO}_{2}$ is in equilibrium with all species above the carbon dominance field and $\mathrm{CH}_{4}$ is in equilibrium with all species below the carbon field.

Fig. 2. Contours on logarithms of partial pressures of $\mathrm{CO}_{2}$ and $\mathrm{CH}_{4}$. Limits of dominance fields of sulfur species from Fig. 1 are shown for reference.

Fig. 3. Contours on logarithms of partial pressures of $\mathrm{H}_{2} \mathrm{~S}$. Limits of dominance fields of sulfur species from Fig. 1 are shown for reference.

Fig. 4. Contours on logarithms of partial pressures of COS. Limits of dominance fields of sulfur species from Fig. 1 are shown for reference. 
(Hinkle and Kantor, 1978; Hinkle and Harms, 1978), although these gases were driven off collectors at high temperatures rather than being measured directly. In spite of these generally encouraging preliminary observations, sulfur gas analysis has not yet been widely applied in mineral exploration, in part because of the uncertainty over the gases that will be given off by decomposing sulfide minerals vs. those produced by microbial activity (cf. Zobell, 1963).

This study was designed to clarify these ambiguous aspects of sulfur gas geochemistry by: (1) prediction of the sulfur gases that would be generated by decomposing sulfide minerals, by use of equilibrium thermodynamic calculations (Garrels and Christ, 1965); and (2) direct measurement of sulfur gases generated by decomposing sulfide minerals in the laboratory. Our results show that sulfur gases generated by decomposing sulfide minerals can be distinguished from the other sulfur gases likely to be formed by microbial processes and thus offer the potential for being useful indicators of sulfide mineral deposits at depth.

\section{EQUILIBRIUM CONCENTRATIONS OF SULFUR GASES}

\section{Results of the calculations}

Figure 1 shows aqueous species of sulfur as well as the dominance fields for native or solid sulfur and for graphite. This figure serves as a reference to Figs. 2 through 10, which show the dependence on $\mathrm{Eh}$ and $\mathrm{pH}$ of the equilibrium partial pressures of $\mathrm{CO}_{2}, \mathrm{CH}_{4}, \mathrm{H}_{2} \mathrm{~S}, \mathrm{COS}, \mathrm{SO}_{2}, \mathrm{CH}_{3} \mathrm{SH}, \mathrm{CS}_{2}$, $\mathrm{S}_{2}$, and $\left(\mathrm{CH}_{3}\right)_{2} \mathrm{~S}_{2}$ in contact with aqueous sulfur species in water at $25^{\circ} \mathrm{C}$ and 1 atmosphere total pressure. Free energies of formation used to calculate these diagrams were obtained from Wagman et al. (1968) and from Robie et al. (1978). These diagrams were calculated for systems with $10^{-2}$ molal total dissolved sulfur or the sum of the partial pressure of $\mathrm{CO}_{2}$ and $\mathrm{CH}_{4}$ equal to $10^{-1}$ atmospheres, or both. Activity and fugacity coefficients were neglected because at these concentrations negligible error is introduced.

The effect of changing the concentration of dissolved sulfur at $\mathrm{pH}=2.5$ can be seen in Fig. 11, which shows partial pressures of carbon and sulfur gases for total soluble sulfur of $10^{-1}, 10^{-2}$, and $10^{-4} \mathrm{molal}$, and with partial pressure of $\mathrm{CO}_{2}$ plus $\mathrm{CH}_{4}$ equal to $10^{-1}$ atmosphere. For each gas, three concentration curves have been shown corresponding to the three soluble sulfur concentrations listed above. The field for carbon is also shown for the sum of partial pressures of carbon gases equal to $10^{-1} \mathrm{~atm}$.

\section{Implications of the calculations}

Figure 11 shows that the relative order of abundance of sulfur gases under equilibrium conditions is $\mathrm{H}_{2} \mathrm{~S}, \mathrm{COS}, \mathrm{CS}_{2}, \mathrm{CH}_{3} \mathrm{SH}$, etc. Figures 2 through 11 show that the sulfur gases are most abundant at low to intermediate oxida- 

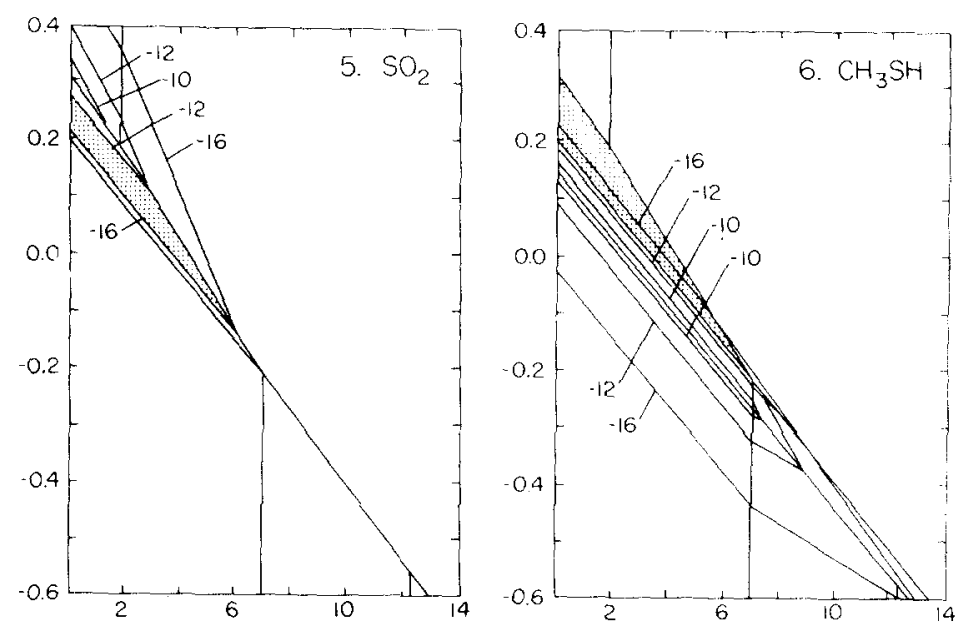

5
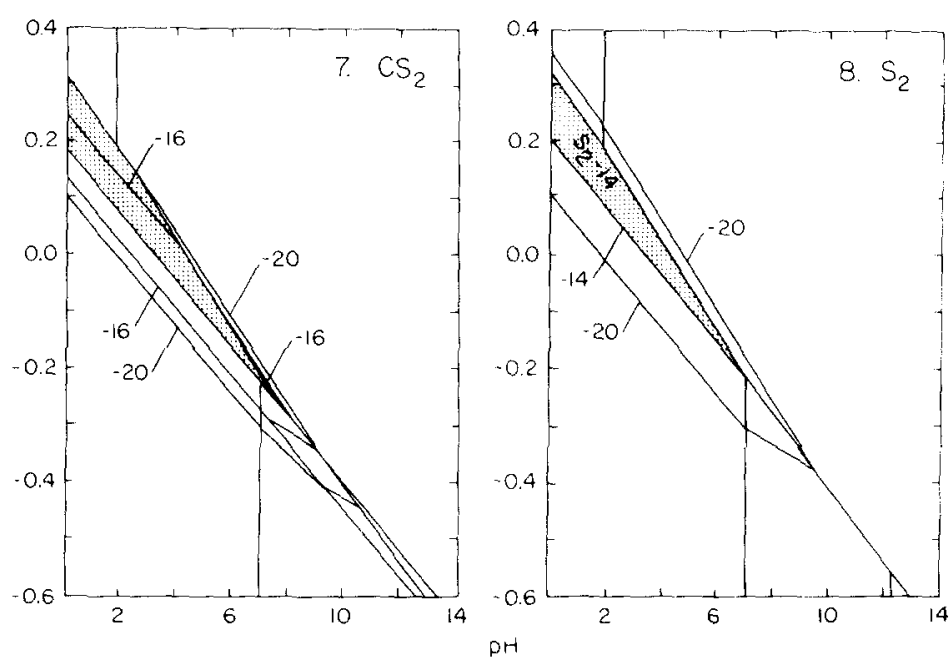

Fig. 5. Contours on logarithms of partial pressures of $\mathrm{SO}_{2}$. Limits of dominance fields of sulfur species from Fig. 1 are shown for reference.

Fig. 6. Contours on logarithms of partial pressures of $\mathrm{CH}_{3} \mathrm{SH}$ (methyl mercaptan). Limits of dominance fields of sulfur specis from Fig. 1 are shown for reference.

Fig. 7. Contours on lgarithms of partial pressures of $\mathrm{CS}_{2}$. Limits of dominance fields of sulfur species from Fig. 1 are shown for reference.

Fig. 8. Contours on logarithms of partial pressures of $S_{2}$. Limits of dominance fields of sulfur species from Fig. 1 are shown for reference. 

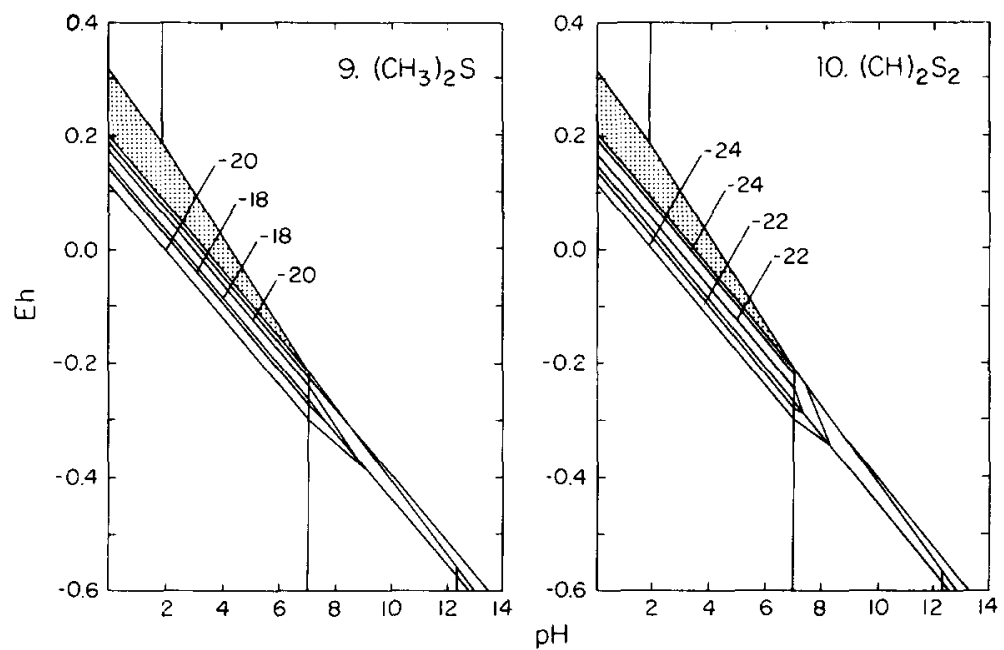

Fig. 9. Contours on logarithms of partial pressures of $\left(\mathrm{CH}_{3}\right)_{2} \mathrm{~S}_{2}$ (dimethyl sulfide). Limits of dominance fields of sulfur species from Fig. 1 are shown for reference.

Fig. 10. Contours on logarithms of partial pressurs of $\left(\mathrm{CH}_{3}\right)_{2} \mathrm{~S}_{2}$ (dimethyl disulfide). Limits of dominance fields of sulfur species from Fig. 1 are shown for reference.

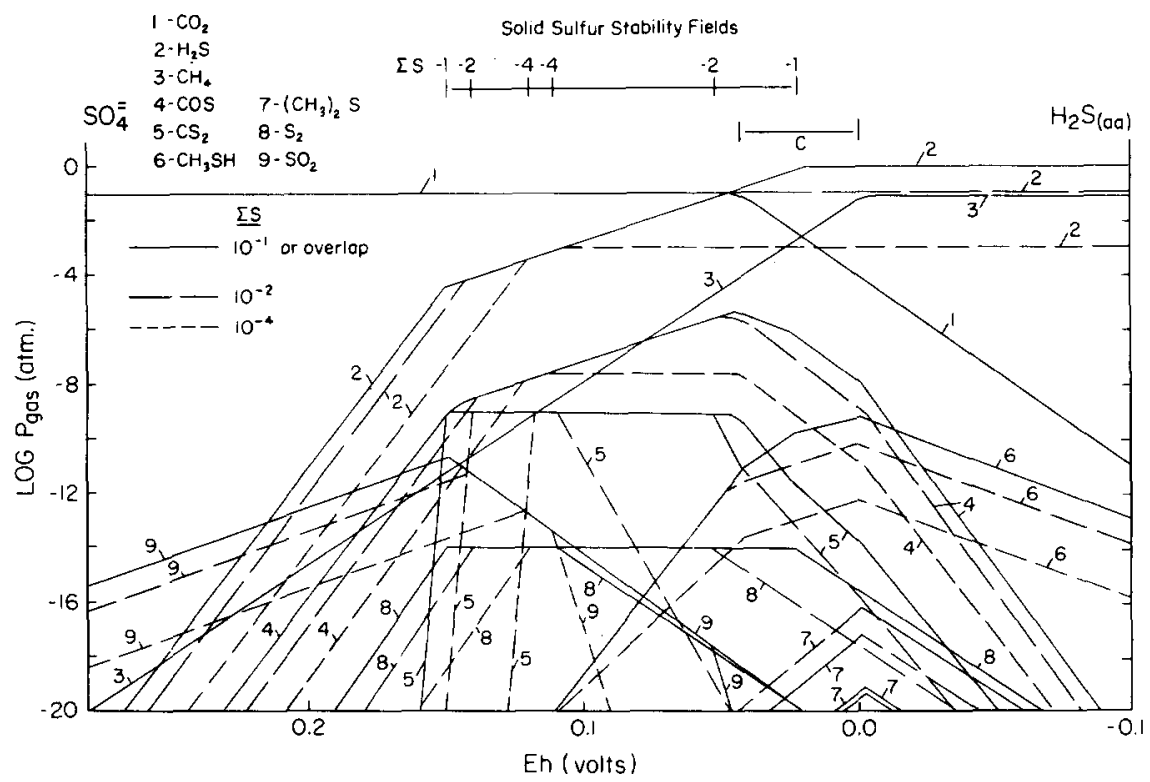

Fig. 11. Sulfur and carbon gases in equilibrium with aqueous sulfur species at $\mathrm{pH}=\mathbf{2 . 5}$, $\mathrm{P}_{\mathrm{CO}_{2}}+\mathbf{P}_{\mathrm{CH}_{4}}=10^{-1} \mathrm{~atm}, \Sigma \mathrm{S}=10^{-1} \mathrm{~m}, 10^{-2} \mathrm{~m}$, and $10^{-4} \mathrm{~m}$. 
tion potentials and neutral to low $\mathrm{pH}$. Only $\mathrm{H}_{2} \mathrm{~S}$ should persist at significant partial pressures under very reducing conditions and at higher $\mathrm{pH}$ values. No sulfur gases should occur at significant equilibrium partial pressures under oxidizing conditions at intermediate to high $\mathrm{pH}$.

Significant partial pressure, or concentration, as used here means a concentration in the gaseous phase high enough to be detected analytically. For sulfur gases, analyses are most easily done with a gas chromatograph, which can detect concentrations of sulfur gas as low as several parts per billion without preconcentration techniques. One ppbv (parts per billion gas, volume per volume basis) corresponds to a gas pressure of $10^{-9}$ atmosphere. Thus, on Figs. 2 through 11, the calculated partial pressure of any sulfur gas species would have to be greater than $10^{-9}$ atmosphere for it to be detected analytically. Evaluation of the diagrams in light of this restriction indicates that equilibrium concentrations of $\mathrm{H}_{2} \mathrm{~S}_{\mathrm{g}}$ under the conditions of these calculations should be detectable over a relatively wide range of Eh and $\mathrm{pH}$, and $\mathrm{COS}$ should be detectable over a restricted range of $\mathrm{Eh}$ and $\mathrm{pH}$.

These results can be further interpreted in relation to the ranges of Eh and $\mathrm{pH}$ observed in nature and the calculated dominance fields of iron sulfides

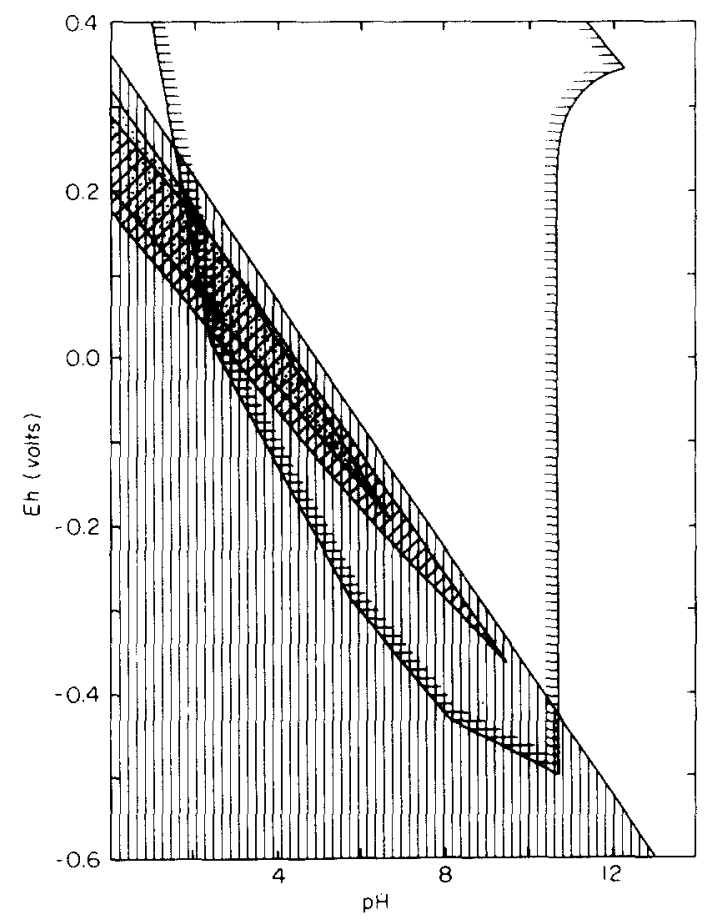

Fig. 12. Field in which $\mathrm{P}_{\mathrm{H}}$ s exceeds $10^{-9}$ atm (vertical ruling), field in which $\mathrm{P}_{\mathrm{COS}}$ exceeds $10^{-9} \mathrm{~atm}^{\text {(diagonal }}$ ruling), and field for solid sulfur (stippled) in relation to natural limits of $\mathrm{Eh}$ and $\mathrm{pH}$ (hachured line) (Baas-Becking et al., 1960). Total dissolved $\mathrm{S}=0.01, \mathrm{P}_{\mathrm{CO}_{2}}+\mathrm{P}_{\mathrm{CH}_{4}}=0.1 \mathrm{~atm}$. 


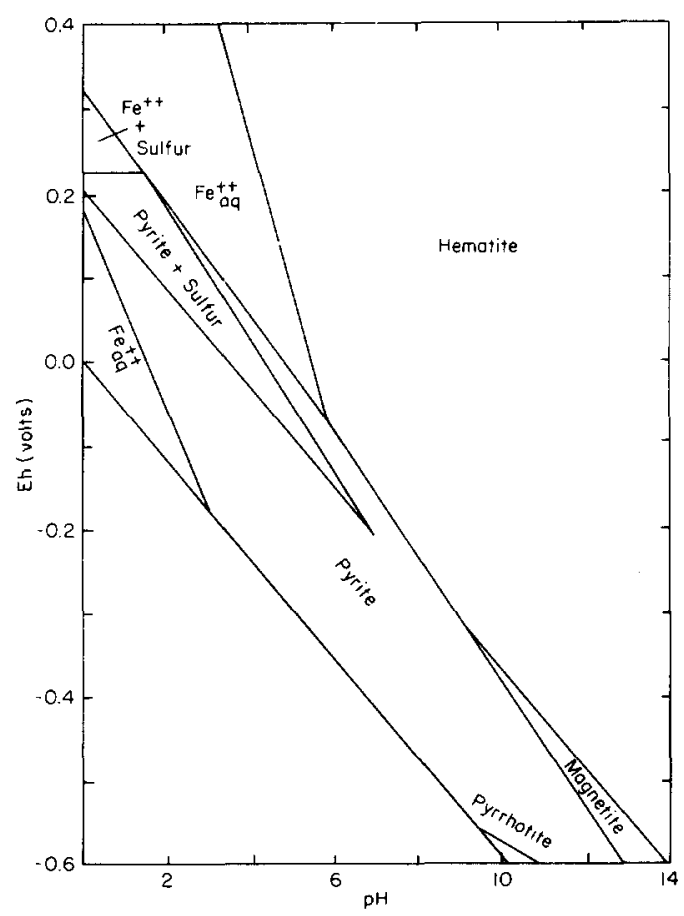

Fig. 13. Equilibrium relationship of iron sulfides and oxides in water at $25^{\circ} \mathrm{C}$ and 1 atm total pressure. $S=10^{-2} \mathrm{~m}$ and total dissolved iron $=10^{-4} \mathrm{~m}$. Siderite is not stable at $\mathrm{P}_{\mathrm{CO}_{2}}+\mathrm{P}_{\mathrm{CH}_{4}}=10^{-1}$ atm for which this diagram was constructed.

and oxides. Baas Becking et al. (1960) have proposed limits of $\mathrm{Eh}$ and $\mathrm{pH}$ in the natural environment on the basis of numerous measurements of waters. Their suggested natural limits, which are superimposed in part on Fig. 12, further restrict the conditions under which sulfur gases can exist at equilibrium in nature. Figure 13 shows the calculated dominance fields of iron sulfides and oxides at a concentration of total dissolved iron equal to $10^{-4}$ molal and under the conditions previously specified for the sulfur gas diagrams. This figure shows the iron phases present in equilibrium with sulfur gases depicted in Figs. 2 through 10. Comparison of these figures with those previously presented suggests that the dominant iron-bearing phase that coexists with sulfur gases and aqueous sulfur species will be pyrite. Another possible phase, siderite, is not stable under the conditions considered in the calculations.

EXPERIMENTAL DETERMINATIONS OF SULFUR GASES

\section{Introduction}

Numerous authors have suggested that reactions involving sulfur at ambient temperature and pressure are very sluggish and that thermodynamic 
equilibrium is seldom attained (Zobell, 1963; Goldhaber and Kaplan, 1974). For this reason, we conducted experiments designed to determine by direct measurement the sulfur gases that are generated by the decomposition of sulfide minerals. These experiments were performed under sterile and nonsterile conditions to evaluate biological effects on sulfur gas generation. Microorganisms are especially influential in mediating the transformation of sulfur from one valence state to another (Roy and Trudinger, 1970).

\section{Experimental methods}

In all experiments, 20 grams of $40--80$ mesh crushed sulfide mineral (pyrite, chalcopyrite, galena, and sphalerite) were added to either of two types of glass vessels. The first type (Vessel A) has a volume of $280 \mathrm{ml}$ and is separated into two compartments by a sintered glass filter disc of 5 micron porosity (Fig. 14). This vessel was used in experiments in which the sulfide mineral was kept moist with $10 \mathrm{ml}$ of water but not saturated. Water was circulated through the crushed sulfide mineral via a peristaltic pump and Tygon tubing. The second type of experimental vessel (Vessel B) has a volume of $180 \mathrm{ml}$ (Fig. 15) and was used in experiments in which the sulfide

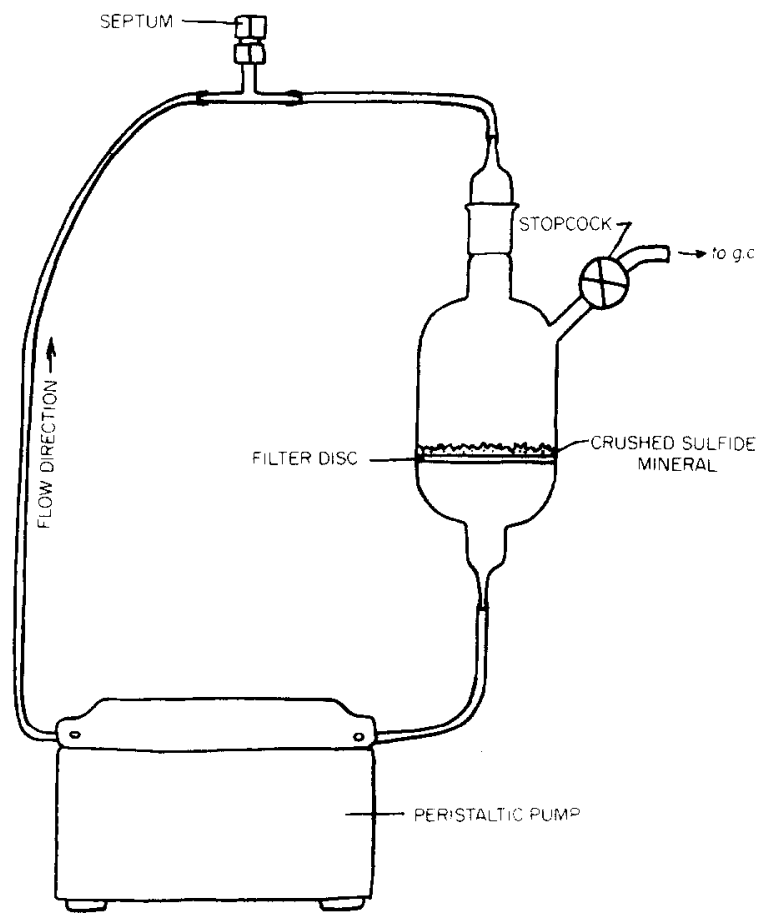

Fig. 14. Experimental vessel A. Note that water is pumped into top of vessel where it drips onto sulfide minerals on fritted glass filter disc. Gas (air, helium) pressure through the septum was used to force sample gas out the stopcock to the gas chromatograph. 


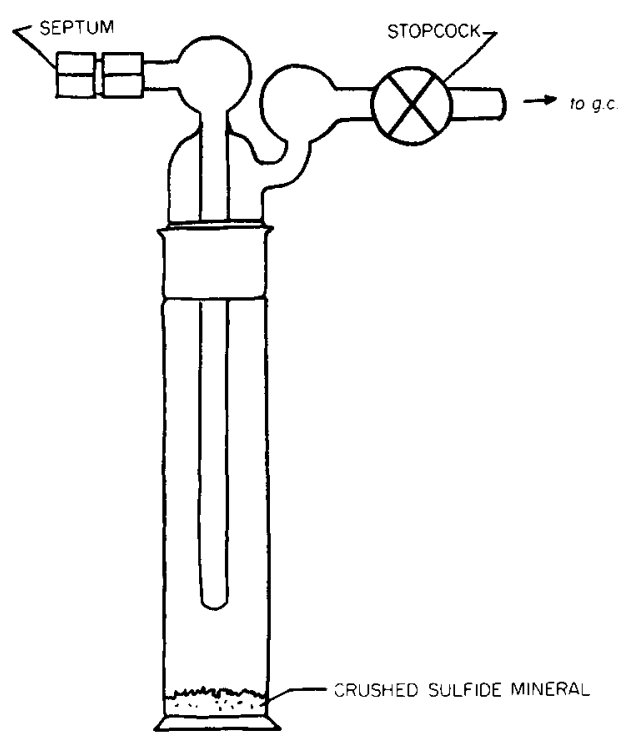

Fig. 15. Experimental vessel B. Sample gas was forced from this vessel in a manner similar to that used in vessel $A$.

mineral was allowed to decompose either dry or completely saturated with $10 \mathrm{ml}$ of water. Gases were sampled from the headspaces of the experimental vessels through glass side stems connected to Teflon-plug stopcocks. A 20 $\mathrm{ml}$ injection of air through a septum connected to the experimental vessel forced a sample into the gas chromatograph for analysis. For sterile experiments the apparatus, minerals, and water were autoclaved, and precautions taken to preserve sterility during set-up and sampling. In a further effort to evaluate biological effects, one set of experiments was performed in which sterile and nonsterile soil (10 grams of 80 mesh dry soil) was added to $10 \mathrm{ml}$ of water and 20 grams of 40-80 mesh crushed pyrite. The experimental vessels were sampled daily for a period of time ranging from 9 to 15 days. At the end of an experiment, $\mathrm{Eh}$ and $\mathrm{pH}$ of the final solutions in the experiments were measured on a Corning Model $10 \mathrm{pH}$ meter. Experimental reliability was assessed by performing all experiments in duplicate.

The headspace samples and standards were analyzed on a Tracor $\mathbf{5 6 0}$ gas chromatograph with a Model $700 \mathrm{~A}$ Hall electrolytic conductivity detector operated in the sulfur mode (Gluck, 1981). The column oven was temperature programmed from $50^{\circ} \mathrm{C}$ to $80^{\circ} \mathrm{C}$. The column oven program held the temperature at $50^{\circ} \mathrm{C}$ for four minutes before heating at a rate of $15^{\circ} \mathrm{C} / \mathrm{min}$ for two minutes. After the column had reached $80^{\circ} \mathrm{C}$, the program maintained this temperature until all gases had been eluted. The reactor temperature for the detector was kept at $820^{\circ} \mathrm{C}$ and reactor base was held at $200^{\circ} \mathrm{C}$. Helium carrier gas flow, air flow to the detector, and methanol 
solvent flow were $25 \mathrm{ml} / \mathrm{min}, 50 \mathrm{ml} / \mathrm{min}$, and $0.5 \mathrm{ml} / \mathrm{min}$, respectively. A 180-cm glass column packed with 60-80 mesh Carbopack B treated with $1.5 \% \mathrm{XE}-60$ resin and $1.0 \% \mathrm{H}_{3} \mathrm{PO}_{4}$ was used to separate the sulfur gases (Supelco, Inc., Bellefonte, PA). Under these operating conditions and using this column, all sulfur gases were separated from one another except dimethyl sulfide and dimethyl disulfide used as standards (Fig. 16). A Carle six-port switching valve (Carle Instruments, Inc., Fullteron, CA) was used to inject gas samples from a two $\mathrm{ml}$ glass sample loop onto the analytical column.

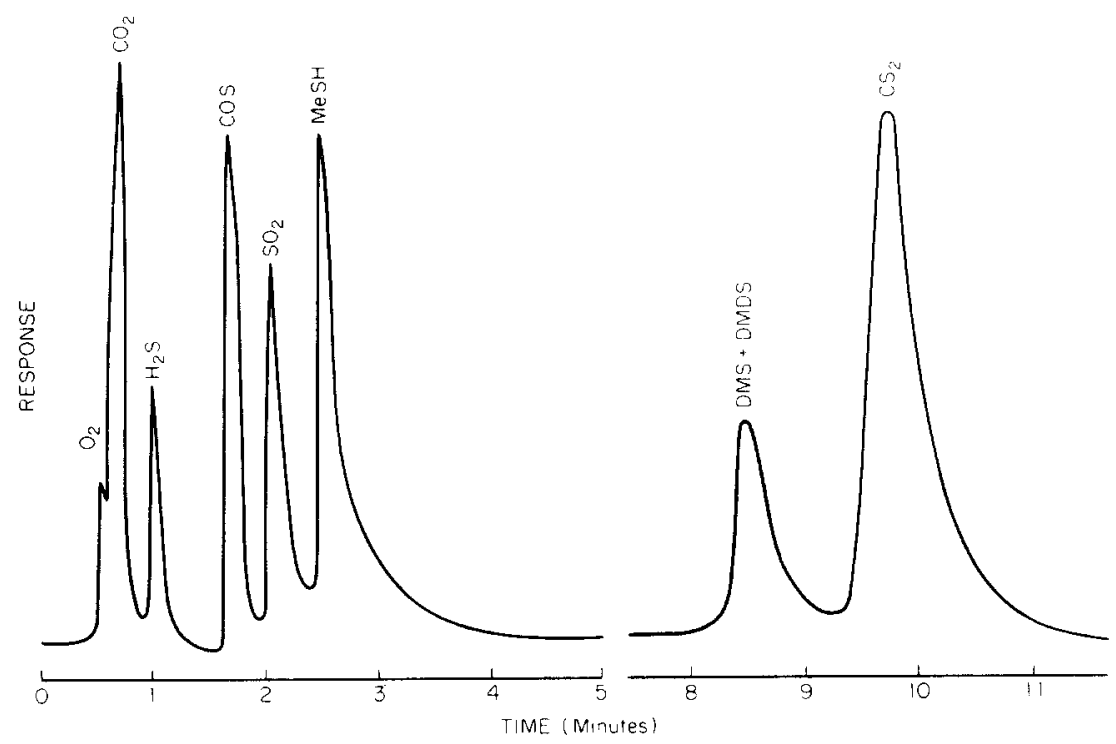

Fig. 16. Chromatogram of sulfur gases used as standards. Note broken time axis.

A permeation tube calibration system provided standard concentrations of $\mathrm{H}_{2} \mathrm{~S}$, COS, $\mathrm{SO}_{2} \mathrm{CH}_{3} \mathrm{SH}$ (methyl mercaptan, $\mathrm{MeSH}$ ), $\left(\mathrm{CH}_{3}\right)_{2} \mathrm{~S}$ (dimethyl sulfide, DMS), and $\mathrm{CS}_{2}$. Permeation tubes were kept in a water bath held at $35^{\circ} \mathrm{C} \pm 0.1^{\circ} \mathrm{C}$ to insure constant permeation rates. Laboratory air provided continual flow over the permeation tubes. When standard concentrations were desired, laboratory air was first passed through a multi-bed absorbent filter (Farwell et al., 1979a) to remove trace water vapor or sulfur gas before passing over the permeation tubes. Dilutent air flow was measured with a calibrated Gilmont flowmeter (VWR Scientific, Inc., Detroit, MI).

\section{Experimental results}

Table I lists our experiments and briefly summarizes our results. Eh and $\mathrm{pH}$ measurements of final solutions from the experiments are recorded in Table II. We further elaborate on the results of our experiments, in order of what we believe to be their significance, as follows: 


\section{TABLE I}

Experiments performed

\begin{tabular}{|c|c|c|}
\hline Sulfide mineral sample ${ }^{1}$ & Conditions $^{2}$ & Sulfur gases detected ${ }^{3}$ \\
\hline Non-sterile pyrite & $\begin{array}{l}\mathbf{M} \\
\mathbf{S}\end{array}$ & $\begin{array}{l}\mathrm{CS}_{2}, \mathrm{COS} \\
\mathrm{CS}_{2}, \mathrm{COS}\end{array}$ \\
\hline Sterile pyrite & $\begin{array}{l}\mathbf{M} \\
\mathbf{S}\end{array}$ & $\begin{array}{l}\mathrm{CS}_{2}, \mathrm{COS} \\
\mathrm{CS}_{2}, \mathrm{COS}\end{array}$ \\
\hline Non-sterile chaclopyrite & $\begin{array}{l}\mathrm{M} \\
\mathbf{S}\end{array}$ & $\begin{array}{l}\mathrm{CS}_{2}, \mathrm{COS} \\
\mathrm{CS}_{2}, \mathrm{COS}\end{array}$ \\
\hline Sterile chalcopyrite & $\begin{array}{l}\mathbf{M} \\
\mathbf{S}\end{array}$ & $\begin{array}{l}\mathrm{CS}_{2}, \mathrm{COS} \\
\mathrm{CS}_{2}, \mathrm{COS}\end{array}$ \\
\hline Non-sterile galena & $\begin{array}{l}\mathbf{M} \\
\mathbf{S}\end{array}$ & $\begin{array}{l}\mathrm{CS}_{2}, \mathrm{COS} \\
\mathrm{CS}_{2}, \mathrm{COS}\end{array}$ \\
\hline Sterile galena & $\begin{array}{l}\mathbf{M} \\
\mathbf{S}\end{array}$ & $\begin{array}{l}\mathrm{CS}_{2}, \mathrm{COS} \\
\mathrm{CS}_{2}, \mathrm{COS}\end{array}$ \\
\hline Non-sterile sphalerite & $\begin{array}{l}\mathbf{M} \\
\mathbf{S}\end{array}$ & $\begin{array}{l}\mathrm{Cs}_{2}, \mathrm{COS} \\
\mathrm{COS}_{4}\end{array}$ \\
\hline Sterile sphalerite & $\begin{array}{l}M \\
S\end{array}$ & $\begin{array}{l}\mathrm{CS}_{2}, \mathrm{COS} \\
\mathrm{COS}_{4}\end{array}$ \\
\hline Non-sterile pyrite + soil & $\mathbf{S}$ & $\mathrm{CS}_{2}, \mathrm{COS}$ \\
\hline Sterile pyrite + soil & $\mathbf{S}$ & $\mathrm{CS}_{2}, \mathrm{COS}$ \\
\hline Non-sterile pyrite ${ }^{5}$ & D & $\mathrm{CS}_{2}, \mathrm{SO}_{2}, \mathrm{COS}$ \\
\hline Non-sterile galena ${ }^{5}$ & D & $\mathrm{CS}_{2}, \mathrm{SO}_{2}, \mathrm{COS}$ \\
\hline
\end{tabular}

' Each experiment was duplicated.

${ }^{2} 10 \mathrm{ml}$ of $\mathrm{pH}=6.5$ water was added to the crushed sulfide mineral in which the mineral was kept either moist (M) with water in Vessel A or saturated (S) with water in Vessel B. Dry (D) experiments contained the sulfide which had been dried overnight at $110^{\circ} \mathrm{C}$ and then added to Vessel $B$.

${ }^{3}$ Detection limits for $\mathrm{COS}=5 \mathrm{ppb}$ and for $\mathrm{CS}_{2}=30 \mathrm{ppb}$. Detection limits for $\mathrm{H}_{2} \mathrm{~S}, \mathrm{SO}_{3}$, and $\mathrm{MeSH}=5 \mathrm{ppb}$ and for DMS and DMDS $=30 \mathrm{ppb}$.

${ }^{4}$ The fact that $\mathrm{COS}$ was detected and $\mathrm{CS}_{2}$ was not probably reflects the higher detection limit of $\mathrm{CS}_{2}$ and its low concentration in these experiments.

${ }^{5}$ The experiments were discontinued after one day of analysis.

(1) The sulfur gases emitted by the decomposition of sulfide minerals under moist and saturated conditions are exclusively, in order of increasing abundance, $\mathrm{CS}_{2}$ and COS. Figure 17 shows a typical chromatogram of a gas sample from a vessel containing pyrite. $\mathrm{H}_{2} \mathrm{~S}$ was conspicuously absent from this and all other analyses of gases formed by decomposing sulfide minerals.

(2) The greatest amounts of sulfur gas are produced by the decomposition of pyrite. Chalcopyrite also yields relatively large amounts of sulfur gas, but galena and sphalerite emit very little. Figure 18 shows this result for experiments conducted under saturated conditions. Under moist conditions, pyrite and chalcopyrite also yielded greater amounts of sulfur gas than galena and sphalerite. 
TABLE II

Eh-pH measurements of final solutions from experiments

\begin{tabular}{|c|c|c|c|}
\hline Experiment & Condition & Eh (mvolts) & $\mathbf{p H}$ \\
\hline Sterile-1 pyrite & $\begin{array}{l}\mathbf{S} \\
\mathbf{M}\end{array}$ & $\begin{array}{l}824 \\
894\end{array}$ & $\begin{array}{l}3.0 \\
3.5\end{array}$ \\
\hline Sterile-2 pyrite & $\begin{array}{l}\mathbf{S} \\
\mathbf{M}\end{array}$ & $\begin{array}{l}790 \\
944\end{array}$ & $\begin{array}{l}3.7 \\
3.4\end{array}$ \\
\hline Non-sterile-1 pyrite & $\begin{array}{l}\mathbf{S} \\
\mathbf{M}\end{array}$ & $\begin{array}{l}970 \\
974\end{array}$ & $\begin{array}{l}3.1 \\
3.2\end{array}$ \\
\hline Non-sterile-2 pyrite & $\begin{array}{l}\mathrm{S} \\
\mathbf{M}\end{array}$ & $\begin{array}{l}914 \\
934\end{array}$ & $\begin{array}{l}3.4 \\
3.4\end{array}$ \\
\hline Sterile-1 chalcopyrite & $\begin{array}{l}\mathbf{S} \\
\mathbf{M}\end{array}$ & $\begin{array}{l}524 \\
844\end{array}$ & $\begin{array}{l}5.7 \\
4.7\end{array}$ \\
\hline Sterile-2 chalcopyrite & $\begin{array}{l}\mathbf{S} \\
\mathbf{M}\end{array}$ & $\begin{array}{l}459 \\
794\end{array}$ & $\begin{array}{l}5.3 \\
4.5\end{array}$ \\
\hline Non-sterile-1 chalcopyrite & $\begin{array}{l}\mathbf{S} \\
\mathbf{M}\end{array}$ & $\begin{array}{l}504 \\
864\end{array}$ & $\begin{array}{l}5.5 \\
4.5\end{array}$ \\
\hline Non-sterile-2 chalcopyrite & $\begin{array}{l}\mathbf{S} \\
\mathbf{M}\end{array}$ & $\begin{array}{l}534 \\
924\end{array}$ & $\begin{array}{l}5.7 \\
4.1\end{array}$ \\
\hline Sterile-1 galena & $\begin{array}{l}\mathbf{S} \\
\mathbf{M}\end{array}$ & $\begin{array}{l}774 \\
704\end{array}$ & $\begin{array}{l}6.2 \\
4.8\end{array}$ \\
\hline Sterile-2 galena & $\begin{array}{l}\mathbf{S} \\
\mathbf{M}\end{array}$ & $\begin{array}{l}724 \\
744\end{array}$ & $\begin{array}{l}6.0 \\
4.9\end{array}$ \\
\hline Non-sterile-1 galena & $\begin{array}{l}\mathbf{S} \\
\mathbf{M}\end{array}$ & $\begin{array}{l}684 \\
734\end{array}$ & $\begin{array}{l}5.9 \\
5.6\end{array}$ \\
\hline Non-sterile-2 galena & $\begin{array}{l}\mathbf{S} \\
\mathbf{M}\end{array}$ & $\begin{array}{l}704 \\
694\end{array}$ & $\begin{array}{l}6.0 \\
5.6\end{array}$ \\
\hline Sterile-1 sphalerite & $\begin{array}{l}\mathbf{S} \\
\mathbf{M}\end{array}$ & $\begin{array}{l}804 \\
849\end{array}$ & $\begin{array}{l}4.7 \\
4.5\end{array}$ \\
\hline Sterile-2 sphalerite & $\begin{array}{l}\mathbf{S} \\
\mathbf{M}\end{array}$ & $\begin{array}{l}834 \\
864\end{array}$ & $\begin{array}{l}5.3 \\
4.6\end{array}$ \\
\hline Non-sterile- 1 sphalerite & $\begin{array}{l}\mathrm{S} \\
\mathrm{M}\end{array}$ & $\begin{array}{l}854 \\
854\end{array}$ & $\begin{array}{l}4.8 \\
4.0\end{array}$ \\
\hline Non-sterile-2 sphalerite & $\begin{array}{l}\mathbf{S} \\
\mathbf{M}\end{array}$ & $\begin{array}{l}884 \\
844\end{array}$ & $\begin{array}{l}5.0 \\
4.4\end{array}$ \\
\hline Sterile-1 pyrite + soil & $\mathbf{S}$ & 674 & 6.4 \\
\hline Sterile-2 pyrite + soil & $\mathbf{S}$ & 674 & 6.6 \\
\hline Non-sterile-1 pyrite + soil & $\mathbf{S}$ & 674 & 6.5 \\
\hline Non-sterile-2 pyrite + soil & $\mathbf{S}$ & 694 & 6.6 \\
\hline
\end{tabular}

In view of the thermodynamic calculations the evolution of carbon-sulfur gases under sterile conditions is surprising. The carbon may have come from $\mathrm{CO}_{2}$, which was not effectively excluded from reaction vessels. Because of the possibility of minute amounts of organic compounds having been adsorbed from laboratory air, or being present in the original pyrite, one 


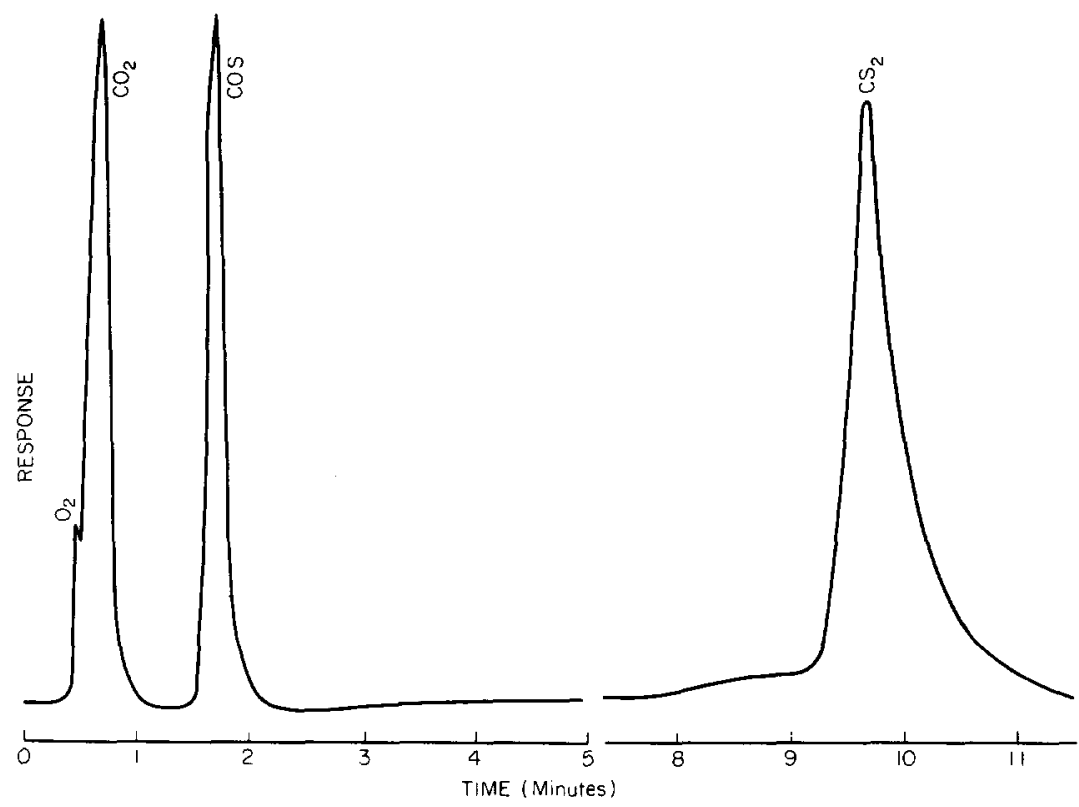

Fig. 17. Chromatogram of sulfur gases formed by the decomposition of pyrite under water saturated conditions.

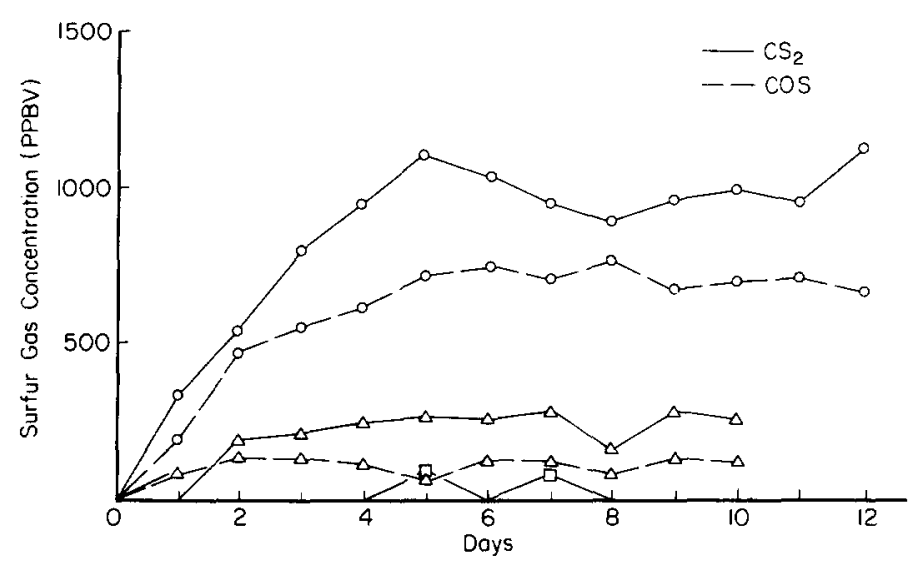

Fig. 18. Sulfur gas concentrations (parts per billion gas, volume per volume basis) from the decomposition of 20 grams of 40-80 mesh pyrite ( $(0)$, chalcopyrite $(\Delta)$, and galena $(\square)$ under water saturated conditions. Concentrations of sulfur gas less than $100 \mathrm{ppbv}$ have not been plotted for the sake of clarity. The concentration of $\mathrm{CS}_{2}$ in the galena experiment shown reached $100 \mathrm{ppbv}$ only twice. Concentrations of $\mathrm{CS}_{2}$ and $\mathrm{COS}$ never reached $100 \mathrm{ppbv}$ in any sphalerite experiments.

experiment was performed using pyrite precleaned with heptane and methanol to remove natural organic material. This test showed no significant difference from otherwise similar experiments. The source of the carbon will be the subject of further investigation. 
(3) The formation of $\mathrm{CS}_{2}$ and $\mathrm{COS}$ from the decomposition of sulfide minerals occurs by inorganic reactions, as indicated by the generation of these gases under sterile as well as non-sterile conditions. Furthermore, in many experiments the amounts of sulfur gas produced by non-sterile experiments was not appreciably different from amounts produced by sterile experiments, which indiates that sulfur gases formed in the reactions are produced dominantly by inorganic processes. Figure 19 shows results of sterile and non-sterile experiments on pyrite and Fig. 20 shows results of similar experiments on chalcopyrite. Note that the patterns of sulfur gas evolution in sterile and non-sterile experiments are very similar. (If there were biological effects manifested in sulfur gas generation, a much greater rate of sulfur gas evolution in the non-sterile experiments would be expected.) Biological effects on sulfur gas generation cannot be completely ruled out, however. In saturated pyrite experiments, the average concentration of COS produced by the decomposition of sterile pyrite for each 12 days of analyses was less than the average concentration of $\operatorname{COS}$ in non-sterile ex-
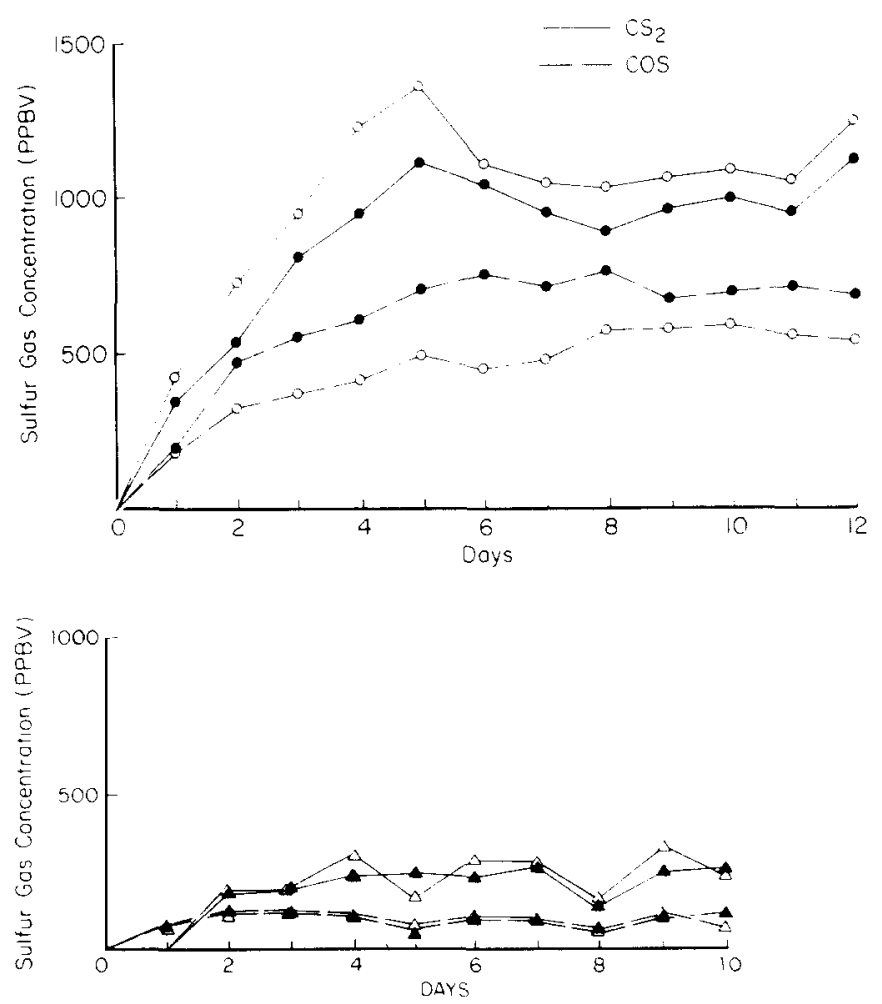

Fig. 19. Sulfur gas concentrations from the decompositon of 20 grams of 40-80 mesh pyrite in sterile $(0)$ and non-sterile $(\bullet)$ experiments under water saturated conditions.

Fig. 20. Sulfur gas concentrations from the decomposition of 20 grams of 40-80 mesh chalcopyrite in sterile $(\Delta)$ and non-sterile $(\Delta)$ experiments under water saturated conditions. 
periments. The average concentration of $\operatorname{COS}$ in sterile experiments ranged from $49 \%$ to $77 \%$ of the average concentration in non sterile experiments. For $\mathrm{CS}_{2}$, the average concentration in sterile experiments was less in 9 out of 12 days of analyses. For these 12 days, the average $\mathrm{CS}_{2}$ concentration in sterile experiments ranged from $87 \%$ to $107 \%$ of the average $\mathrm{CS}_{2}$ concentration in non-sterile experiments. These comparisons offer the best evidence suggesting biological effects on sulfur gas generation. Table III lists analytical data for both sterile and non-sterile experiments. Note that although the saturated pyrite experiments suggest biological interaction, other experiments do not. For example in the saturated chalcopyrite experiments, the average concentration of $\operatorname{COS}$ in sterile experiments was lower than the average concentration in non-sterile experiments only 6 out of 10 days of analyses. The average concentration of $\mathrm{CS}_{2}$ in sterile experiments was less than the average concentration in non-sterile experiments only one out of 10 days. Thus, the data suggest but do not completely prove a biological enhancement of sulfur gas production.

In an effort to obtain more biologically active media than just the nonsterile sulfide mineral, non-sterile soil was added to pyrite. Corresponding sterile pyrite + soil experiments were also performed. Figure 21 shows the results of these experiments. Note the resemblances of the patterns of sulfur gas generation and the amounts of $\mathrm{CS}_{2}$ in both experiments. This suggests that there was no significant biological effect on sulfur gas generation in this preliminary experiment. Curiously, COS was not generated in great amounts in sterile experiments. Comparison of Fig. 21 with Fig. 19 shows that levels of sulfur gas concentrations in the pyrite + soil experiments were

\section{TABLE III}

Data analyses of sterile and non-sterile experiments

\begin{tabular}{|c|c|c|c|c|}
\hline Experiments & $\begin{array}{l}\text { No. of days } \\
A<B\end{array}$ & $\begin{array}{l}\text { Range of values } \\
\text { for ratio* } A / B\end{array}$ & $\begin{array}{l}\text { No. of days } \\
C<D\end{array}$ & $\begin{array}{l}\text { Range of values } \\
\text { for ratio* } C / D\end{array}$ \\
\hline $\begin{array}{l}\text { Saturated pyrite } \\
\text { Moist pyrite }\end{array}$ & $\begin{array}{l}12 / 12 \\
12 / 15\end{array}$ & $\begin{array}{l}0.49-0.77 \\
0.49-1.25\end{array}$ & $\begin{array}{r}9 / 12 \\
11 / 15\end{array}$ & $\begin{array}{l}0.87-1.07 \\
0.59-2.61\end{array}$ \\
\hline $\begin{array}{l}\text { Saturated chalcopyrite } \\
\text { Moist chalcopyrite }\end{array}$ & $\begin{array}{l}6 / 10 \\
2 / 11\end{array}$ & $\begin{array}{l}0.60-1.54 \\
0.97-1.25\end{array}$ & $\begin{array}{r}1 / 10 \\
10 / 11\end{array}$ & $\begin{array}{l}0.93-3.15 \\
0.73-1.22\end{array}$ \\
\hline $\begin{array}{l}\text { Saturate d galena } \\
\text { Moist galena }\end{array}$ & $\begin{array}{l}5 / 12 \\
0 / 10\end{array}$ & $\begin{array}{l}0.33-1.00 \\
1.00-1.75\end{array}$ & $\begin{array}{l}2 / 12 \\
0 / 10\end{array}$ & $\begin{array}{l}0.33-1.00 \\
2.0\end{array}$ \\
\hline $\begin{array}{l}\text { Saturated sphalerite } \\
\text { Moist sphalerite }\end{array}$ & $\begin{array}{l}4 / 9 \\
8 / 10\end{array}$ & $-\overline{0.22-1.00}$ & $-3 / 10$ & $\overline{0.50-1.20}$ \\
\hline Saturated pyrite + soil & $0 / 10$ & $12.0-35.5$ & $3 / 10$ & $0.73-1.52$ \\
\hline
\end{tabular}

A: Average concentration of COS in sterile experiments.

B: Average concentration of $\mathrm{COS}$ in non-sterile experiments.

C: Average concentration of $\mathrm{CS}_{2}$ in sterile experiments.

D: Average concentration of $\mathrm{CS}_{2}$ in non-sterile experiments.

* Ratio computed for each day of analyses. Does not include values of zero in numerator or demoninator. 


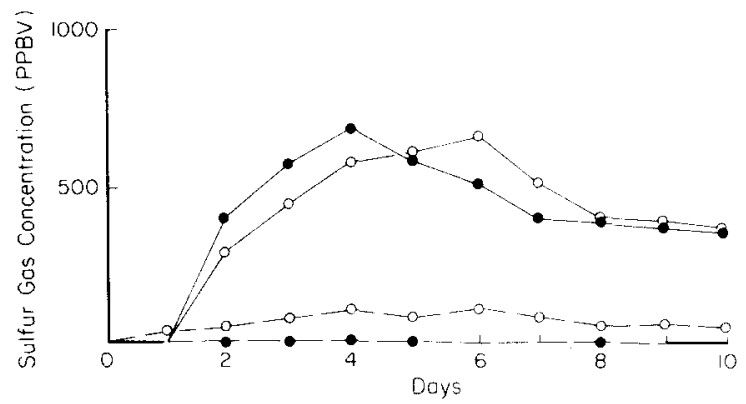

Fig. 21. Sulfur gas concentrations from the decomposition of 20 grams of 40-80 mesh pyrite +10 grams of -80 mesh soil in sterile $(\circ)$ and non-sterile $(\bullet)$ experiments under water saturated conditions.

lower than in the similar pyrite experiments shown in Fig. 19. We interpret this to mean either adsorption of the sulfur gases onto the soil or reaction of the gases with the soil.

(4) A greater amount of sulfur gas is produced when sulfide minerals are moist than when completely water saturated. Experiments conducted with moist sulfide mineral in Vessel A consistently produced more sulfur gas than experiments with water saturated sulfide mineral in Vessel B. It is noteworthy, however, that measureable amounts of sulfur gases were detected above completely submerged sulfide minerals.

(5) Sulfur dioxide was detected in completely dry samples of the sulfide minerals studied, but very small amounts of water inhibited $\mathrm{SO}_{2}$ emissions.

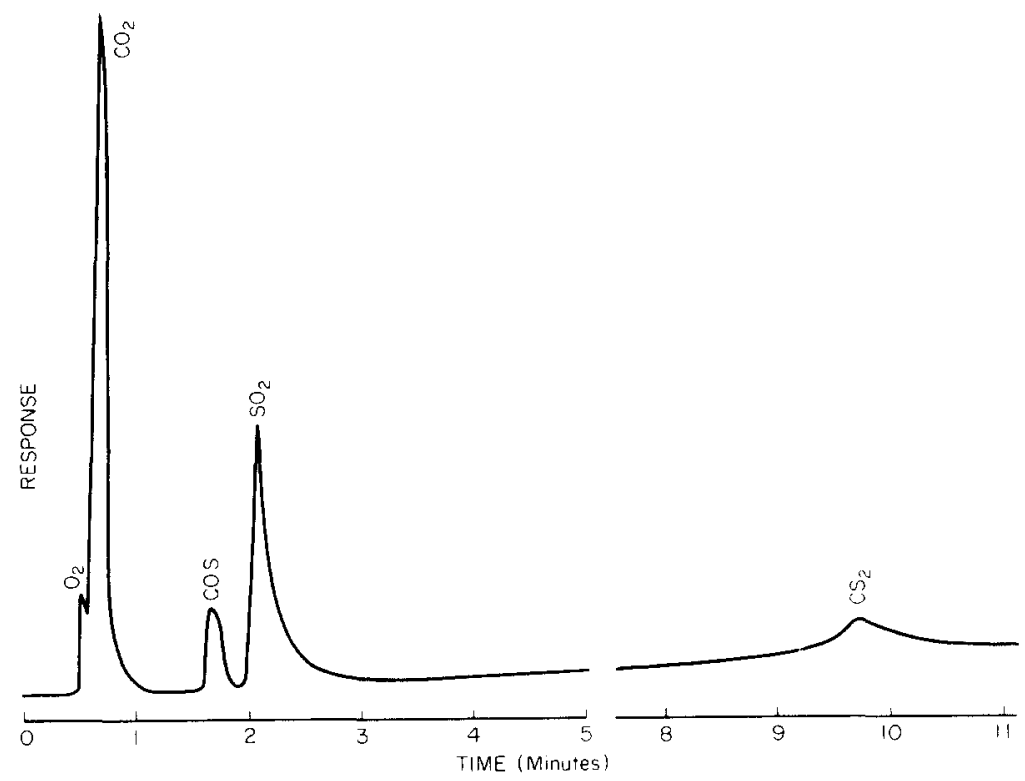

Fig. 22. Chromatogram of sulfur gases formed by the decomposition of galena under dry conditions. 
Figure 22 is a chromatogram of a gas sample from Vessel B containing galena. This preliminary experiment was discontinued because we felt completely dry conditions are rare in environments in which sulfide mineral decomposits decompose. We noted that no $\mathrm{SO}_{2}$ was detected when small amounts of water (less than one $\mathrm{ml}$ ) were present. We interpret this to reflect the high solubility of $\mathrm{SO}_{2}$ in water.

(6) If the sulfur gases evolve at a constant rate, concentrations in the head spaces of the reaction vessels should reach a steady value during the course of about two weeks because the daily sampling would eventually remove sulfur at the same rate. However, the approach to a steady state from this cause alone would be far less abrupt than that observed, indicating either that the rate of evolution decreases within the first 3 or 4 days, as would arise from diffusion through a thickening oxidized surface boundary layer on the mineral, or that sulfur gases are lost in other ways, such as by further oxidation of the gas to $\mathrm{SO}_{2}$.

\section{DISCUSSION}

Comparison of equilibrium thermodynamic calculations and experimental results

Our equilibrium thermodynamic calculations predict that the decomposition of sulfide minerals will at equilibrium produce, in order of abundance, $\mathrm{H}_{2} \mathrm{~S}, \mathrm{COS}, \mathrm{CS}_{2}$, etc. These calculations show also that only $\mathrm{H}_{2} \mathrm{~S}$ and COS should form at levels high enough to be detected analytically, and that the Eh-pH fields of importance for these gases are relatively restricted. These predictions show little resemblance to the actual distribution of sulfur gases observed to form by decomposing sulfide minerals. $\mathrm{H}_{2} \mathrm{~S}$ was not detected in any of the experiments. COS was formed in high enough levels to be detected analytically, as was $\mathrm{CS}_{2}$. Furthermore, as Fig. 23 illustrates, $\mathbf{C S}_{2}$ and COS were formed in the experiments under oxidizing conditions at Eh and $\mathrm{pH}$ conditions far from those predicted in Figs. 4, 7, and 11 as being most nearly stable. This indicates that disequilibrium occurs in the experiments performed, even after periods as long as two weeks. Thus the calculated equilibrium concentrations of sulfur gases provide a basis for assessing the occurrence and magnitude of disequilibria in our systems, but do little to predict the sulfur gases likely to be generated in natural settings in which disequilibria are the rule.

The experiments indicate that sulfide mineral deposits can be expected to generate $\mathrm{CS}_{2}$ and $\mathrm{COS}$ by the decomposition of sulfide minerals. The results also suggest that deposits containing pyrite will produce more gas than similar deposits that do not contain pyrite. The generation of $\mathrm{CS}_{2}$ and $\mathrm{COS}$ when sulfide minerals are moist or completely saturated implies that they can be very useful indicators of sulfide mineral deposits under a variety of conditions. $\mathrm{SO}_{2}$ was found to form from sulfide minerals in completely dry 


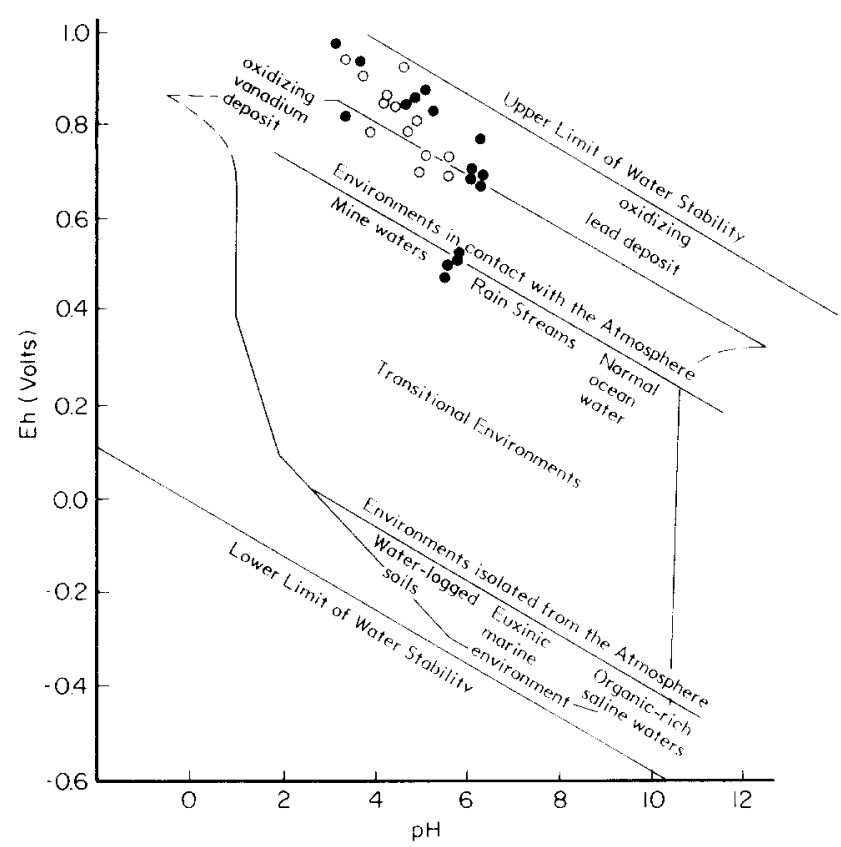

Fig. 23. Eh-pH measurements of final solutions from moist $(0)$ and water saturated (•) sulfide mineral experiments in which $\mathrm{CS}_{2}$ and $\mathrm{COS}$ were detected. Outlined area depicts natural limits of Eh and pH suggested by Baas Becking et al. (1960). Environments indicated are from Garrels and Christ (1965).

experiments, but the high solubility of $\mathrm{SO}_{2}$ in water makes its detection unlikely in all but the most arid environments. Therefore, $\mathrm{SO}_{2}$ is a much less favorable indicator of sulfide minerals than $\mathrm{CS}_{2}$ and COS. For $\mathrm{CS}_{2}$ and COS to be truly indicative of sulfide mineral decompositon, it must be shown that these gases are unlikely to be generated in great amounts by other processes in nature.

\section{Other possible sources of sulfur compounds}

Other possible sources of volatile sulfur compounds, in addition to sulfur gases that are produced by the decomposition of sulfide minerals, include the decomposition of sulfur-containing organic compounds in soil and microbial reduction of sulfate to produce $\mathrm{H}_{2} \mathrm{~S}$. Volatile sulfur compounds are released from soils largely by microbial degradation of sulfur-bearing organic compounds. Volatile sulfur compounds formed from aerobic soils include dimethyl sulfide (DMS, $\left(\mathrm{CH}_{3}\right)_{2} \mathrm{~S}$ ), dimethyl disulfide (DMDS, $\left(\mathrm{CH}_{3}\right)_{2} \mathrm{~S}_{2}$ ), methyl mercaptan (MeSH, $\left.\mathrm{CH}_{3} \mathrm{SH}\right)$, and $\mathrm{COS}$, whereas anaerobic soils produce DMS, DMDS, MeSH, $\mathrm{CS}_{2}$, and COS (Kadota and Ishida, 1972; Banwart and Bremner, 1974, 1975, 1976a, 1976b; Bremner and Steele, 1978.) Banwart and Bremner (1976) have demonstrated that when normally 
aerobic soils are saturated with water, approximately 10 times more sulfur gases are emitted than before saturation. Out of 25 Iowa soils, Banwart and Bremner found only four soils that would emit detectable levels of sulfur gas under aerobic conditions and all of this was DMS. When the same soils were saturated with water, 14 of them released volatile sulfur, mainly as DMS (average $90 \%$ ) with some $\mathrm{COS}, \mathrm{CS}_{2}, \mathrm{MeSH}$, and DMDS. $\mathrm{H}_{2} \mathrm{~S}$ has never been detected when normally aerobic soils become saturated (Bremner and Steele, 1978). Anaerobic soils with abundant sulfide present will emit relatively large amounts of $\mathrm{H}_{2} \mathrm{~S}$ and $\mathrm{CS}_{2}$ (Farwell et al., 1979b). Such soils may be expected in restricted environments such as tidal marshes and swamps. These observations indicate that the detection of anomalous levels of $\mathrm{CS}_{2}$ and $\mathrm{COS}$ relative to the other sulfur gases such as DMS will be indicative of sulfide minerals at depth and thus are a powerful exploration tool, provided that the exploration survey is not carried out over anaerobic soils (eg. samples are collected below these soils if they are present).

The microbial reduction of sulfate and resultant production of $\mathrm{H}_{2} \mathrm{~S}$ is well established (Postgate, 1959; Zobell, 1963). Although $\mathrm{H}_{2} \mathrm{~S}$ was not shown to emanate directly from the sulfide minerals in our experiments, it might be argued that $\mathrm{H}_{2} \mathrm{~S}$ can be generated by microbial reduction of sulfate formed by an oxidizing mineral deposit. We think this is unlikely. The microbes responsible for the reduction of sulfate are strict anaerobes and can not tolerate high levels of acidity (Baas Becking et al., 1960; Goldhaber and Kaplan, 1974). Therefore, $\mathrm{H}_{2} \mathrm{~S}$ produced by sulfate reduction can only occur in environments that contain no dissolved oxygen have moderate to high levels of $\mathrm{pH}$, and high concentrations of sulfate. Oxidizing mineral deposits in the subsurface are not likely to generate $\mathrm{H}_{2} \mathrm{~S}$ because of the associated high acidity and the oxygen content in ground water that is toxic to the microbes responsible for the reduction of sulfate. Furthermore, voltile $\mathrm{H}_{2} \mathrm{~S}$ will only be detected from environments with low levels of soluble iron and other cations capable of precipitating this reactive molecule (Ponnamperuma, 1972; Alexander, 1974). The high concentrations of metals in water near oxidizing mineral deposits further preclude the possibility of volatile $\mathrm{H}_{2} \mathrm{~S}$ generation from metalic sulfide deposits.

\section{CONCLUSIONS}

Equilibrium thermodynamic calculations predict that decomposing sulfide minerals will give off sulfur gases in the following order of abundance: $\mathrm{H}_{2} \mathrm{~S}$, $\mathrm{COS}, \mathrm{CS}_{2}, \mathrm{CH}_{3} \mathrm{SH},\left(\mathrm{CH}_{3}\right)_{2} \mathrm{~S}_{2}$ or $\mathrm{SO}_{2}$ or $\mathrm{S}_{2}$. In contrast, experimental decompsion of moist and saturated sulfide minerals yields only $\mathrm{CS}_{2}$ and $\mathrm{COS}$, usually in that order of decreasing abundance. $\mathrm{SO}_{2}$ was detected only over completely dry sulfide minerals. Of the sulfide minerals tested, pyrite generates the most gas, chalcopyrite the next largest amount and sphalerite and galena yield little or no gas. $\mathrm{CS}_{2}$ and $\mathrm{COS}$ can also be derived from soils, but soils also yield large amounts of $\left(\mathrm{CH}_{3}\right)_{2} \mathrm{~S}_{2},\left(\mathrm{CH}_{3}\right)_{2} \mathrm{~S}$ and $\mathrm{CH}_{3} \mathrm{SH}$, which 
are not given off by decomposing sulfide minerals. Thus, it appears likely that analysis of $\mathrm{CS}_{2}$ and $\mathrm{COS}$ can be used to detect buried sulfide mineral deposits.

\section{ACKNOWLEDGEMENTS}

Research for this paper has been supported by National Science Foundation Grant DAR-80-08116. We are grateful to Andrew Watson and Donald Stedman at the University of Michigan and Steven Gluck at DOW Chemical Company, Midland, Michigan for their assistance in setting up the gas chromatography laboratory, and to Peter Vandenbergh and Frizell Vaughn at the University of Michigan and Paul Voltz at Eastern Michigan University for their advice and help in achieving sterile conditions and assessing the maintenance of sterility at the conclusion of experiments.

\section{REFERENCES}

Alexander, M., 1974. Microbial formation of environmental pollutants. Adv. Appl. Microbiol., 18: 1-73.

Baas Becking, L.G.M., Kaplan, I.R. and Moore, D., 1960. Limits of natural environment in terms of $\mathrm{pH}$ and oxidation-reductino potentials. J. Geol., 68: 243-284.

Banwart, W.L. and Bremner, J.M., 1974. Gas chromatographic identification of sulfur gases in soil atmospheres. Soil Biol. Biochem., 6: 113-115.

Banwart, W.L. and Bremner, J.M., 1975. Formation of volatile sulfur compounds by microbial decompositon of sulfur-containing amino acids. Soil Biol. Biochem., 7: $359-364$.

Banwart, W.L. and Bremner, J.M., 1976a. Volatilization of sulfur from unamended and sulfate-treated soils. Soil Biol. Biochem., 8: 19-22.

Banwart, W.L. and Brmener, J.M., 1976b. Evolution of volatile sulfur compounds from soils treated with sulfur-containing organic materials. Soil Biol. Biochem., 8: 439443.

Bremner, J.M. and Steele, C.G., 1978. Role of microorganisms in the atmospheric sulfur cycle. Adv. Microbiol. Ecol., 2: 115-201.

Elinson, M.M., Pashkov, Yu.N., Agabobov, G.M. and Ignat'eva, I.B., 1970. Research on gas aureoles around copper-molybdenum ore bodies. In: Outline of the Geochemistry of Mercury, Molybdenum, and Sulfur in the Hydrothermal Process. Nauka Publ., Moscow (In Russian). Engl. abstract in Chem. Abstr., 74: item 5470.

Farwell, S.O., Gluck, S.J., Bamesburger, W.L., Schutte, T.M. and Adams, D.F., 1979a. Determination of sulfur-containing gases by a deactivated cryogenic enrichment and capillary gas chromatographic system. Anal. Chem., 51:609-615.

Farwell, S.D., Sherrard, A.E., Pack, M.R. and Adams, D.F., 1979b. Sulfur compounds volatilized from soils at different moisture contents. Soil Biol. Biochem., 11: 411415.

Garrels, R.M. and Christ, C.L., 1965. Solutions, Minerals, and Equilibria. Harper and Row, New York, N.Y., 450 pp.

Gluck, S.J., 1981. Performance of the Model 700A Hall electrolytic conductivity detector as a sulfur selective detector. J. Chromatogr. Sci., 19: 235-238.

Goldhaber, M.B. and Kaplan, I.R., 1974. The sulfur cycle. In: I.R. Goldberg (Editor), The Sea, Vol. 5. Wiley-Interscience, New York, N.Y., pp. 569-655. 
Hinkle, M.E. and Harms, T.F., 1978. $\mathrm{CS}_{2}$ and $\mathrm{COS}$ in soil gas at the Roosevelt Hot Springs known geothermal resource area, Beaver County, Utah. J. Res. U.S. Geol. Surv., 6: $571-578$.

Hinkle, M.E. and Kantor, J.A., 1978. Collection and analysis of soil gases emanating from buried sulfide mineralization, Johnson Camp Area, Cochise County, Arizona. J. Geochem. Explor., 9: 209-216.

Kadota, H. and Ishida, Y., 1972. Production of volatile sulfur compounds by microorganisms. Ann. Rev. Microbiol., 26: 27-138.

Lovell, J.S., Hale, M. and Webb, J.S., 1980. Vapour geochemistry in mineral exploration. Min. Mag., pp. 229-239.

Lucero, D.P., 1971. Performance characteristics of permeation tubes. Anal. Chem., 43: 1744-1749.

Ponnamperuma, F.N., 1972. The chemistry of submerged soils. Adv. Agron., 24: 29-96.

Postgate, J.R., 1959. Sulfate reduction by bacteria. Ann. Rev. Microbiol., 13: 505-520.

Robie, R.A., Hemingway, B.S., and Fisher, J.R., 1978. Thermodynamic properties of minerals and related substances at $298.15 \mathrm{~K}$ and 1 bar $\left(10^{5}\right.$ pascals $)$ pressure and at higher temperatures. U.S. Geol. Surv. Bull., 1452, U.S. Gov't Printing Office, Washington.

Rose, A.W., Hawkes, H.E. and Webb, J.S., 1979. Geochemistry in Mineral Exploration Academic Press, New York, N.Y., pp. 490-517.

Rouse, G.E. and Stevens, D.N., 1971. The use of sulfur dioxide gas geochemistry in the detection of sulfide deposits. Ann. Meet. Am. Inst. Mining and Metall. Eng. New York, March 3, 1971. Abst. in Mining Eng., 1971: 22:65.

Roy, A.B. and Trudinger, P.A., 1970. The Biochemistry of Inorganic Forms of Sulfur. Cambridge University Press, 400 pp.

Shipulin, F.K., Genkin, A.D., Distler, V.V., Komarov, P.U., Malinovskii, E.P., Ozerova, N.A., Perel'man, A.I., Rekharskii, V.I., Roxanov, Yu. A., Filimonova, L.G., Chernyshev, V.F. and Elinson, M.M., 1973. Some aspects of the problem of geochemical methods of prospecting for concealed mineralization. J. Geochem. Explor., 2: 193-235.

Wagman, D.D., Evans, W.H., Parker, V.B., Harlow, I., Bailey, S.M. and Schumm, R.H., 1968. Selected values of chemical and thermodynamic properties. National Bureau of Standards, Tech. Note 270-3, $264 \mathrm{pp}$.

Zobell, C.F., 1963. Organic geochemistry of sulfur. In: I.A. Breger (Editor), Organic Geochemistry. Pergamon, New York, N.Y., pp. 543-578. 